先天性鼻咽腔閉鎖不全症における軟口蓋の組織学的所見 一いわゆる粘膜下口蓋裂について——

\author{
長谷川昌宏・吉田広・大野康亮・道健一 \\ 山口朗*
}

\title{
Histological examination of the soft palate in patients with congenital velopharyngeal incompetence With regard to so-called submucous cleft palate-
}

\author{
Masahiro Hasegawa - Hiroshi Yoshida - Kohsuke Ohno \\ Ken-ichi MichI Akira Yamaguchi ${ }^{*}$
}

\begin{abstract}
This study was carried out to investigate the histological characteristics of the soft palate in three patients with congenital velopharyngeal incompetence. These patients were diagnosed as type Ia congenital velopharyngeal incompetence classified by cephalometric radiography with contrast media. The tissues examined consisted of the medial zone of the soft palate excised from the three patients and seven normal cadavers. These specimens were sectioned successively at two- or three-millimeter intervals on the frontal direction. The medial zone of the soft palate in all patients were noted macroscopically to be thinner than those of the control group. Histologically, fewer muscle fibers, more fibrosis of the interstitum and misdirection of fibers were found to varying degrees in the three patients compared with the normal cadavers.
\end{abstract}

Key words: congenital velopharyngeal incompetence, submucous cleft palate, soft palate

\section{緒言}

いわゆる先天性鼻咽腔閉鎖不全症には各種の症型が含 まれていることが知られているが，その本態に関しては いまだ不明な点が多い.

本疾患の症型を, Owsley $5^{1)}$, Randall 5², Hoopes $5^{3)}$ 江鼻咽腔閉鎖不全の原因に従って分類し，われわれ

昭和大学菌学部第 1 口腔外科学教室

(主任：道 健一教授)

* 昭和大学歯学部口腔病理学教室 （主任：吉木周作教授）

First Department of Oral and Maxillofacial Surgery, School of Dentistry, Showa University (Chief: Prof. Ken-ichi Michi)

* Department of Oral Pathology, School of Dentistry, Showa University (Chief: Prof. Shusaku Yoshiki)

受付日：昭和 62 年 4 月 30 日
は軟口蓋造影 $\mathrm{X}$ 線規格写真に基づいて本应を 5 群に大別

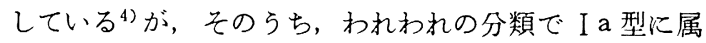
する症例は軟口蓋が短く, かつ, 菲薄であるという形態 的な特徵を有するものであり, Calnan 5)のいらいわゆる 粘膜下口蓋裂であることが多い.今回はわれわれの分類 でI a 型に属し, 臨床的にいわゆる粘膜下口蓋裂と診断 された症例の軟口蓋の形態を組織学的に検索したので報 告する.

\section{研究対象および研究方法}

\section{1. 研究対象}

研究対象は昭和 52 年 8 月〜 57年 5 月に昭和大学歯科病 院第 1 口腔外科入言語障害を主訴として来院した患者の らち，明瞭な口蓋裂がみられないにもかかわらず開放性 畺声を呈する先天性鼻咽腔閉鎖不全症患者 3 例（男：1 例, 女： 2 例）で, 軟口蓋造影X線規格写真所見によっ て, いずれも吉田ら ${ }^{4)}$ の分類で先天性奥咽腔閉鎖不全症 の I a 型と診断された症例である（表1）。これらの症 
表 1 対象莚例

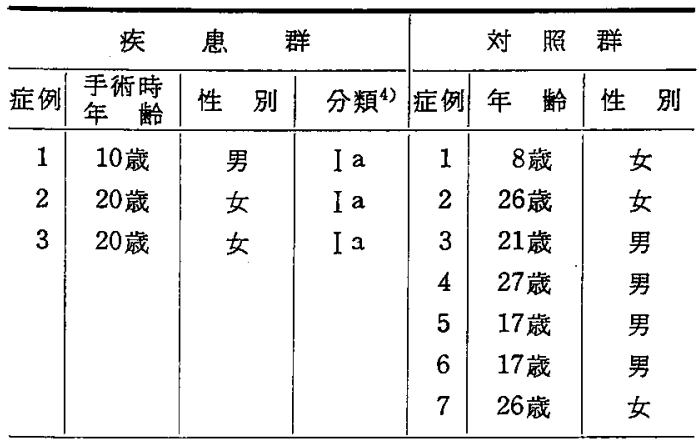

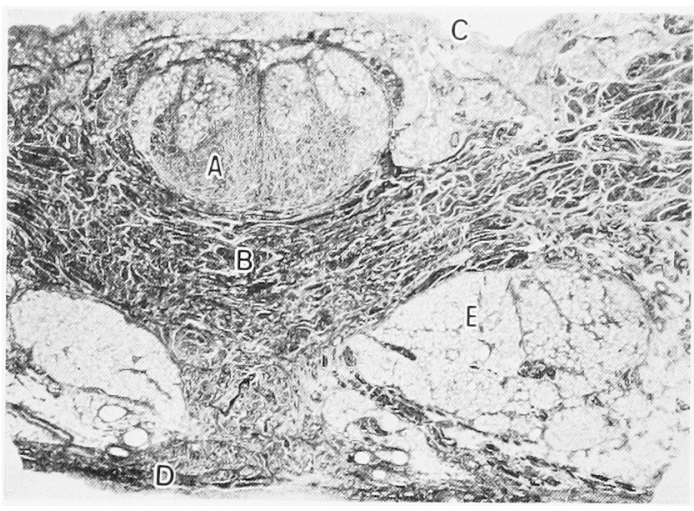

写真 1 病理組織学的所見一対炤群の㳄口蓋正中部 前方部所見(Azan-Mallory染色， ×2.5)-
A. 縱走筋群
B. 横走筋群
C. 舜腔粘膜
D. 口腔粘膜
E. 唾液腺

例は口腔内所見でいずれもCalnan の3 徵候（軟口蓋正 中部透過性, 口蓋垂裂, 硬口蓋後緣部のV型欠損）を有 し, いわゆる粘膜下口蓋裂之診断され, 軟口蓋後方延長 術 (push back operation) および咽頭弁移植術を同時に 施行された。手術時年龄は庭例 $1 か ゙ 10$ 歳，症例 2,3 は 20歳であった。.な扰, 対照群として生前に口腔内に異常 が認められず，しかも発音が正常であったと判定された 日本人屍体 7 例（男: 4 例, 女： 3 例，8２7歳）を検 索した。

\section{2. 研究方法}

1) 組織学的観察

軟口蓋後方延長術 (push back operation) および咽頭 弁移植術施行時に, 疾患群より得られた軟口蓋前端部か ら口蓋垂までの幅約 $8 \mathrm{~mm}$ の軟口蓋正中部の組織片を10 \%中性ホルマリン緩衛夜で固定後, 約 2 3 $\mathrm{mm}$ 間隔で 前頭断に 6〜 7か所切り出し, 通法飞従いパラフィン切 片を製作した後, Hematoxylin-Eosin 染色, Azan-Mallory 染色, Van-Gieson 染色, PAS 染色 (diastase 消化 試験む含む), PTAH 染色, Masson Trichrome 染色を

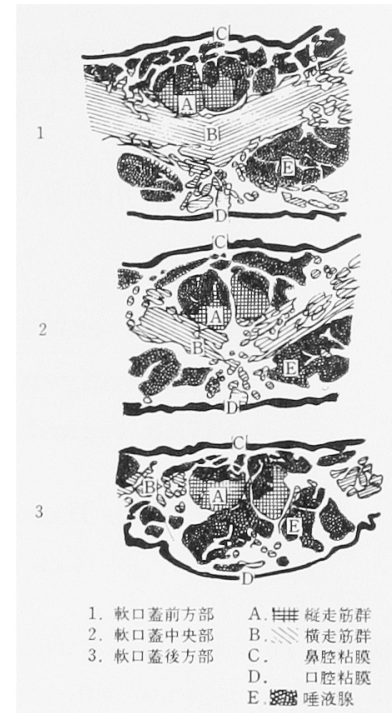

図 1 対照群の軟口蓋正中部病理組 織学的所見シェーマ

施し観察した．さらに，軟口蓋正中部の全体にわたる組 織学的变化を前後的に検討するため, 各切り出し部にお ける筋線維の分布状態を組織写真からトレースし, 軟口 蓋の組織像を準立体的に解明した，対照群についても幅 約 $8 \mathrm{~mm}$ の軟口蓋正中部組織を切除して同様の方法で観 察を行った。

2) 軟口蓋造影 $X$ 線規格写真所見

手術直前に吉田 ${ }^{4)}$ の方法によって軟口蓋造影 X線規 格写真撮影を行い, 得られたX線所見より㳄口蓋の形態 拉よび機能を測定した。

\section{研 究 結 果}

\section{1 組織学的所見}

1) 対照群

腔粘膜上皮之口蓋粘膜上皮の間汇，横走する筋群と 縱走する筋群が認められた，横走する筋群は口蓋正中部 を横断して左右に連絡し正中部を中心にほぽ左右対称性 に分布していた（写直1）。この横走筋群は準立体的に 観察すると，採取した軟口蓋の硬口蓋側（前方）から口 蓋垂やや前方部（後方）までの各切り出し部で認められ た，一方，儊走する筋群は，類円形ない儿楕円形の筋線 維よりなり，口蓋正中よりやや離れた部にほぼ左右対称 性にみられた。この縦走筋群は準立体的に観察すると， 軟口蓋最前方部から約 $8 \mathrm{~mm}$ までの各切り出し部で認め られたが，正中部で交文する所見はみられなかった（図 1). これらの横走筋群, 緥走筋群はともに密に分布す る筋線維より構成されていたが，口蓋垂直前部では笳線 


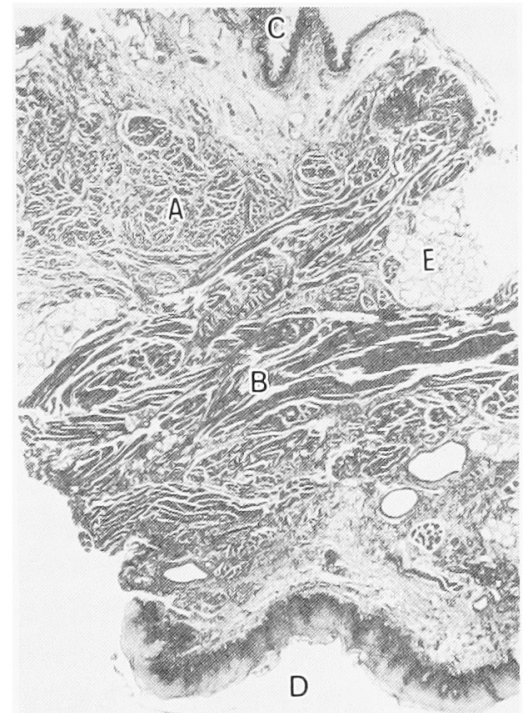

写真 2 病理組織学的所見(Azan-Mallory 染 色, $\times 2.5)$

症例 1 軟口蓋正中部所見
A. 縱走筇群
B. 横走筇群 C. 與腔粘膜
D. 口腔粘膜
E. 唾夜腺

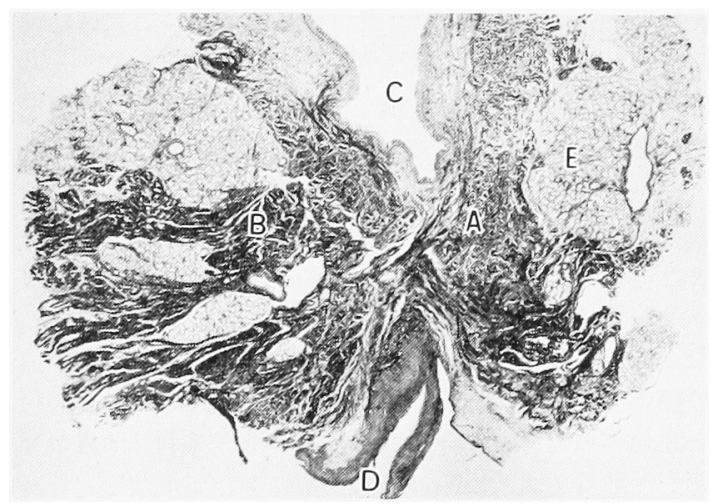

写真 3 病理組織学的所見 (Azan-Mallory 染色, $\times 2.5)$

症例 2 の数口蓋正中部前方部所見
A. 轺走筋群
B. 横走筋群
C. 鼻腔粘膜
D. 口腔粘膜
$\mathrm{E}$. 唾液腺

維の分布密度が柾な程走筋群しかみられなかった．さら に, 大部分の切り出し部で，横走筋群をはさむよらに， 上方には鼻腺，下方には口蓋腺が左右対称に認められ た。なお゙，横走笳群，㖪走筋群いずれにも横紋の不明瞭 化や染色性の不均一などを呈する筋線維がしばしば認め られた。

\section{2）疾患群}

疾患群 3 症例に共通した組織学的所見は，筋線維の分

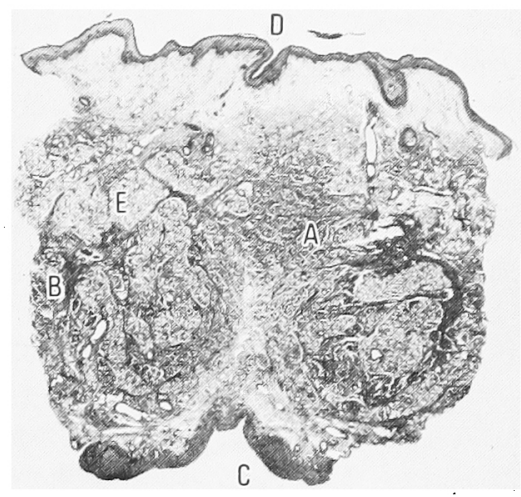

写真 4 病理組織学的所見 (Azan-Mallory 染色, $\times 2.5)$

症例 3 の敷口蓝正中部所見
A. 稌走筋群
B . 横走筋群
C. 鼻腔粘膜
D. 口腔粘膜
E。曈液腺

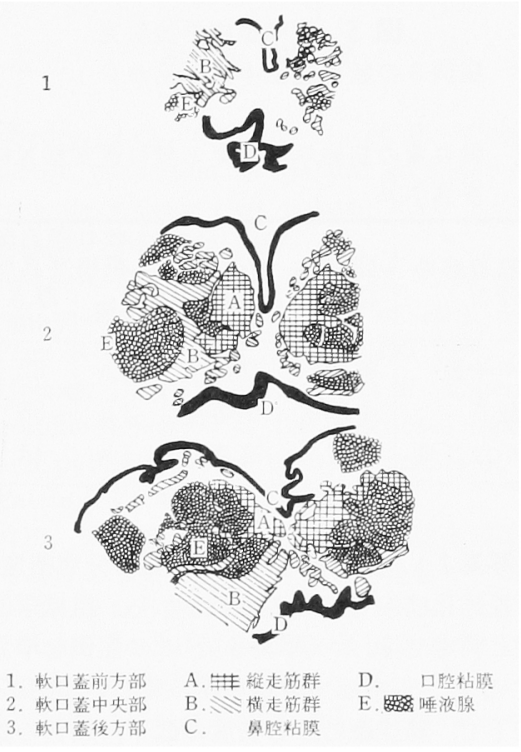

図 2 病理組織学的所見

症例 2 の軟口蓋正中部所見のシェーマ

布密度の低下と間質の線維化であった。これらの所見は 軟口蓋正中部に限局してみられ，正中よりやや離れた部 位では顕著ではなかったまた，同一症例でも前後的部 位によって程度に差がみられた。一方，一部の症例にの みみられた所見としては，筋線維が線維珄結合組織で置 換され，筋の欠損を思わせる像がみられた。これらの組 織学的所見（軟口蓋正中部筋線維の分布密度と間質の線 維化の程度) から組織学的変化を総合的に評価した。 の結果, 庭例 1 では, 笳線維の分布密度はやや柾で, 間 質の線維化も軽度であり, 組織学的変化は軽度と判定さ 


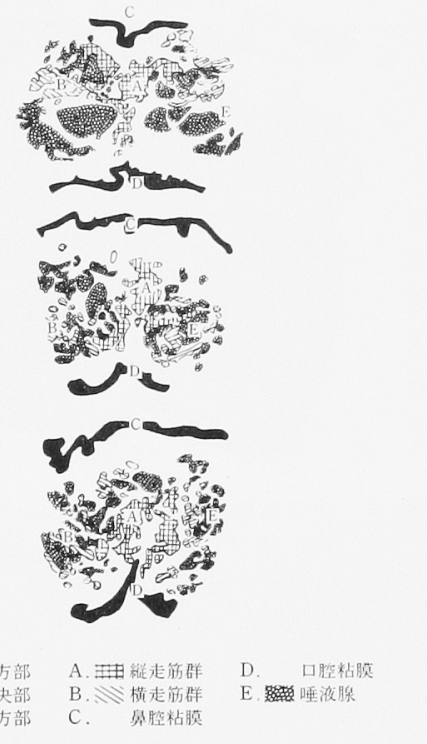

図 3 病理組織学的所見

症例 3 の軟口蓋正中部所見のシェーマ

表 2 軟口蓋の組織学的所晃と軟口蓋造影X線規格 写真所見

\begin{tabular}{|c|c|c|c|c|c|c|}
\hline \multirow{2}{*}{ 症例 } & \multirow{2}{*}{$\begin{array}{l}\text { 笳線維の } \\
\text { 分布 }\end{array}$} & \multirow{2}{*}{$\begin{array}{l}\text { 間質の } \\
\text { 線維化 }\end{array}$} & \multirow{2}{*}{$\mid \begin{array}{l}\text { 筋の䒔縮 } \\
\text { 分布 }\end{array}$} & \multicolumn{3}{|c|}{$\begin{array}{l}\text { 謷口蓋造影X線 } \\
\text { 規格真所見 }\end{array}$} \\
\hline & & & & 分類 & $\begin{array}{l}\text { 厚さ } \\
(\mathrm{mm})\end{array}$ & $\begin{array}{l}\text { 動き } \\
\text { (mm) }\end{array}$ \\
\hline 1 & 中柾 & 軽度 & 軽度 & I a & 32 & 126 \\
\hline 2 & 柾 & 中等度 & 中等度 & I a & 58 & 53 \\
\hline 3 & かなり疎 & 高度 & 高度 & I a & 14 & 108 \\
\hline
\end{tabular}

れた（写真 2）。症例 2 では，筇線維の分布密度は柾で， 間質の線維化は中等度であることから，組織学的変化は 中等度と判定された（写真了）。この症例を準立体的に 観察すると，正中部で鼻腔粘膜の著しい宿凹がみられ， その直下で，筋線維の分布密度の低下，間質の線維化が 認められた（図2）。充た，本例では，対照群にみられ たよらなロ蓋正中部の横走筋群はみられず，同部に綐走 ないしは部分的に横走する筋群が認められた。

症例 3 では，口蓋正中部に和ける筋線維の分布密度は かなり䟱で, 間質の線維化む顕著であり, 組織学的変化 を高度と判定した（写真 4)，この症例でも鼻腔粘膜正 中部に陷凹が認められ，組織学的変化はその直下に限局 し，しかも顕著であった。この症例を準立体的に钼察す ると，口蓋正中部ではわずかに筋線維がみられたが，横 走筇群は全く消失し，大部分の断面で著明な線維化が認 められ（図3）。

なお，対照群を含めていずれの症例に特いてる組織学 的変化の程度とは関係なく横就の不明膫化や染色性の不
均一などを星する筋線維がみられた。

\section{2. 組織所見と軟口䕊造影 $\mathbf{x}$ 線規格写真との対比}

今回の疾患群は 3 例之も軟口蓋造影X線規格写真所見 から同じI a 型と診断されたが，これらの症例のX線写 真上での計測值をみると，軟口蓋の厚さと動きに差が認 められた。これらの計測値を組織学的変化軽度の定例 1 と組織学的変化高度の症例 3 とで比較すると，症例 3 の 方が軟口蓋の厚さが薄く軟口蓋の動きが不良であるとい ら結果が得られたが，組織学的变化中等度の㱏例 2 を含 めると組織学的変化と軟口蓋の厚さ，動きとの間に直接 的な関係は認められなかった（表 2).

\section{考}

察

先天性奥咽腔閉鎖不全症の診断に関しては議論のある ところであるが，口腔内所見のみにより先天性鼻咽腔閉 鎖不全症と粘膜下口蓋裂とに区別している報告が多い． しかし，粘膜下口蓋裂を言葉どおりに「粘膜下で筋層の 断裂した症例」と定義するならば，口腔内所見のみで両 者を判定することが困難な症例が多い，そのため，われ われは両者を一括して先天性鼻咽腔閉鎖不全症とした方 が適切であると考えている，従来，いわゆる粘膜下口蓋 裂の定型的な症例之診断されているのは Calnan の3 徽候 ${ }^{5)}$ (軟口蓋正中部透過性，口蓋垂裂，硬口蓋後縁部 のV型欠損）を3つとも有した症例でありわれわれの 分類で I a 型に属する症例である.今回はこれらの定型 的な粘膜下口葢裂症例について組織学的検討を行った。

従来のいわゆる粘膜下口蓋裂を含めた先天性粤咽腔閉 鎖不全症の軟口蓋の組織学的所見についての報告をみる と, Calnan ${ }^{5)}$, Gylling ら ${ }^{6)}$ は, 粘膜下口蓋裂について検 索し，硬口蓋欠損部值下で組織学的に筋の欠損がみられ たと報告し，Fára らうは，同様に粘膜下曰蓋裂について の検索で症例を軽度，中等度，高度と分類し，筋の欠損 と筋線維の走行を報告している．また，木村方は彼が分 類した非口蓋裂，仮性口蓋裂症例について検索し，それ らの症例においては筋の萎縮度, 軟口蓋の筋線維分布密 度の低下，間質の線維化がみられ，これらの所見より本 疾患の本態は軟口蓋正中部の筋の萎縮と報告している。

本研究の結果では, Calnan ${ }^{5)}$, Gylling 5 (), Fára ら $^{7)}$ と同様に軟口蓋正中部に限局した筋の分布密度の低下と 線維化が各应例に共通して認められた，しかし，本検索 で明らかなように同一症例に括いても準立体的に観察す ると部位により組織像が暴なっていることから，軟口蓋 の一断面の所見のみから筋の萎縮か笳の発育不全かを判 定することは不適当と考えられる。

われわれは垁患群に和ける組織所見を総合的に組織学 的変化軽度, 中等度, 高度と判定したが,このような所 見は何らかの原因で軟口蓋正中部に萎維あるいは発育不 全が起こり，その 2 次的な変化として筋の線維化が生し 
たためと思われるが，その変化が何に起因するものであ るかはさらに検討が必要であろう。

先天性畄咽腔閉鎖不全症では, 軟口蓋造影X線規格写 真所見などによる運動観察所見から軟口蓋の筋の走行異 常の存在が推測されているが, 従来の組織学的所見につ いての報告は軟口蓋の一断面しか観察していないため, 本疾患の軟口蓋の筋の走行異常を組織学的に証明するこ とができなかった。本研究において剖検例と本疾患例の 軟口蓋を準立体的に観察して雨者の筋の走行状態を比較 検討した結果，前方部において，対照群では口蓋帆挙筋 と思われる横走筋群と口蓋帆張筋と思われる縦走筋群が みられたが，疾患群では横走筋群が認められず，縱ない し斜走筋群のみが認められた。この所見は本疾患の軟口 蓋の形態異常の本態が口蓋帆挙筋の筋線維の走行異常で あることを証明するものであると考える。

筋線維の横紋の消失, 染色性の不均一などの所見を, 本疾患に打汁組織学的特改として挙げている報告 ${ }^{8)}$ が みられるが，本研究では対照群においても同様の所見が みられたことから、このような所見が本疾患にお汁る特 徵的な所見とは断定できなかった。

今回の結果から組織学的所見と軟口蓋造影X線規格写 真所見との間に量的な相関関係はみられなかったが， $\mathrm{X}$ 線造影所見 I a 型の共通した組織的特改として正中部に おける筋の発育不全あるいは筋の萎縮と思われる所見が 認められ，結果的に軟口蓋筋層断裂のあったことが証明 され, 今回観察した I a 型の 3 症例はいずれも組織学的 にも粘膜下口蓋裂であったと判定された。しかし，I a 型のなかにも，軟口蓋の厚さが症例によって異なること および今回の対照应例数が少ないことなどから I a 型が すべて組織学的に粘膜下口蓋裂であると結論づけること はできないと考えられる。

\section{総括}

軟口蓋造影X線規格写真により先天性鼻咽腔閉鎖不全 症の I a 型と診断され, Calnan の 3 改候”を有するいわ ゆる粘膜下口蓋裂症例の軟口蓋の形態異常の本態を明ら かにする目的で, 手術時に採取し得た軟口蓋正中部組織 および剖検例より得られた健常者の同部の組織を組織学 的に検索し，その組織学的所見に基ついて準立体的に比 較検討した。 また，併せて本症の組織学的所見と軟口蓋 造影X線規格写真所見を対比した。その結果次の結論を 得た。
1. 疾患群では症例によって程度の差はあるが，軟口 蓋正中部の筋線維の分布密度の低下と間質の線維化が共 通した所見として認められここれらの所見から軟口蓋正 中部の筋の発育不全あるいは萎縮が考えられた。

2. 対照群では，軟口蓋正中部に横走筋群と軟口蓋正 中部を中心に鼻腔側よりに左右対称性な颂走笳群が認め られたが，疾患群では，軟口蓋正中部には横走筋群が認 められず大部分の筋群が綎走している所見が認められ た。これらの所見より本症における筋線維の走行異常が 考えられた。

3. 組織学的所見と軟口蓋造影X線規格写真所見との 間に量的な相関関係は認められなかったが，結果的に 今回対象となった I a 型の 3 症例は, いずれも軟口蓋に 筋層断裂があり組織学的に粘膜下口蓋裂と結論づけられ た。

本論文の要旨は昭和 58 年 4 月 3 日, 第 37 回日本口腔科 学会総会に扣いてロ演発表した。

\section{引用 文 献}

1) Owsley, J.Q., Chierici, G., et al.: Cephalometric evaluation of palatal dysfunction in patients without cleft palate. Plast Reconstr Surg 39: 562-568 1967.

2) Randall, P., Baker, F.P., et al.: Cleft palatetype speech in the absence of cleft palate. Plast Reconstr Surg 25: 484-495 1960.

3) Hoopes, J.E., Dellon, A.L., et al.: Cineradiographic definition of the functional anatomy and pathophysiology of the velopharynx. Cleft Palate J 7: 443-454 1970.

4) 吉田広, 道健一, 他: 軟口蓋造影 $\mathrm{X}$ 線規格 写真による先天性龙咽腔閉鎖不全症の分類につ いて。 日口外誌 28：813-822 1982.

5) Calnan, J.: Submucous cleft palate. Br J Plast Surg 6: 264-282 1954.

6) Gylling, U. and Soivio, A.I.. Submucous cleft palates. Surgical treatment and results. Acta Chir Scand 129: 282-287 1965.

7) Fára, M., Hrivnakova, J., et al.. Submucous cleft palates. Acta Chir Plast 13: 221-234 1971.

8）木村 照：口蓋裂を伴わない鼻咽腔閉鎖不全症 32 症例の治療経験一非口蓋裂と仮性口蓋裂の実 態一。耳息臨床 70：597-621 1977. 